\title{
The first-largest shareholder and the attractiveness of investing in Polish dividend companies $^{* * *}$
}

\author{
Aleksandra Pieloch-Babiarz ${ }^{1}$ \\ PhD, Department of International Finance and Investments, Faculty of Economics and Sociology, \\ University of Lodz
}

JEL Classification: G30, G32, G35

\begin{abstract}
The purpose of this article is to examine the attractiveness of investing in shares of listed companies that regularly pay out dividends depending on the type of the first-largest shareholder. In order to achieve the aim of the paper, two following research questions we formulated: 1) in which companies, broken down by type of the first-largest shareholder, is the highest dividend payment observed? 2) considering the main shareholder, owning shares of which dividend companies is most beneficial for a stock market investor? Furthermore, the research hypothesis is: when investing in dividend, the most attractive investments are those companies in which the most shares are held by institutional investors and the State Treasury. The research was conducted on non-financial companies listed on the Warsaw Stock Exchange in the years 2005-2019 that regularly paid out dividends. The main research method was the classical technique for order of preference by similarity to ideal solution (i.e., TOPSIS) in which stimulants and destimulants were selected in a way which enables to assess the investment attractiveness from the point of view of a long-term stock market investor interested in dividend. Moreover, the Pearson correlation matrix and descriptive statistics were used. In order to conduct the computation we used the statistical software Statistica 13.5 and Excel.

The research revealed that the highest dividends were paid out by these companies in which the first-largest shareholder was the institutional investor. In addition, our calculations based on a synthetic indicator showed that the most attractive investments (in terms of stock market investor interested in so called 'dividend investing') were shares of these companies in which the main shareholder was an institutional investor, individual investor and legal person. In all these types of companies, the average value of dividend payout ratio was higher than in the entire research group. The fourth position in terms of investment attractiveness was occupied by the companies in which managers held the most shares (these companies paid out the lowest dividends in the entire research group). The last place in the ranking was taken by the companies in which the State Treasury was the main shareholder (these companies, despite the payment of high dividends, turned out not to be attractive investment due to their financial condition, and in particular, very high debt).
\end{abstract}

Keywords: investment attractiveness; dividend payouts; first-largest shareholder; synthetic indicator; the Warsaw Stock Exchange.

Corresponding author:

${ }^{1}$ E-mail addresses: aleksandra.pieloch@eksoc.uni.lodz.pl

ORCID ID: 0000-0001-7885-1284

(c) 2021 A.Pieloch-Babiarz

doi: https://doi.org/10.26642/ppa-2021-1(3)-3-11 


\section{Introduction}

In general, the investment attractiveness of shares is understood as a such involvement of capital that will make the stock market investor achieve the highest income at taking an acceptable investment risk. Investment income may take the form of capital gain (which is related to an increase in the company's market value) and dividends (that is paid out of the company's net profit). Typically, stock market speculators, who are short-term investors, are interested in this first form of income, while dividends are usually of interest to long-term investors. Long-term investors treat dividends as a regular source of income, and therefore expect companies to conduct a stable dividend policy. In line with the clientele effect, they are looking for dividend companies with an appropriate payout policy. A company that meets their expectations in this area seems to be the most attractive investment. Furthermore, long-term investing in stocks of dividend companies is so common that it has got its term we call it 'investing in dividend' or 'dividend investing'.

Choosing a dividend company suitable for investment involves the analysis of many different factors influencing its investment attractiveness. One of these determinants is the company's ownership structure. Therefore, there is a cognitively and practically justified need to examine the investment attractiveness of dividend companies in terms of their ownership structure. The purpose of the article is to examine the attractiveness of investing in shares of listed companies that regularly pay out dividends depending on the type of the first-largest shareholder. This objective fits into the current stream of research regarding the fundamental factors determining dividend payouts and is important due to the efficiency of capital investment. Furthermore, it was formulated to get further knowledge of ownership structure as a determinant dividend. Although there are a lot of studies in this research area, there is still a research gap in the attractiveness of investing in shares of dividend companies in terms of the first-largest shareholder.

The remainder of this article is organized as follows. Section 2 is focused on the literature review. Section 3 identifies the previously unresolved issues and the formulates research hypotheses. Section 4 details research methodology and methods. Section 5 presents the main results of empirical research. Section 6 highlights the main concluding remarks.

\section{Literature review}

Stock market investors take into account a number of different factors when making investment decisions. However, the basic investment criterion is the possibility of making a profit. This profit may take the form of capital gain or dividend. The dividend is of particular interest to long-term investors that - investing their capital for many years - are looking for companies that will provide them with regular and stable dividend income [11]. The achievement of their investment goals is possible, in particular, after an investment decision as the consequence of analysis of not only the company's dividend policy (understood as a strategy of dividing the net profit into the part paid to shareholders in the form of dividend and part left in the company for development purposes), but also the company's financial condition. The financial standing of the company is not only an essential factor in making investment decisions, but also one of the determinants of conducting a dividend policy [17].

In the literature, the most important financial determinants of dividend payment include the following factors: a) liquidity according to the agency theory highly liquid companies pay out dividends to reduce agency costs [14]; b) profitability - based on the signaling theory, it should be indicated that companies that achieve high net profits may pay out dividends in order to send a positive signal to the market about their financial condition [12]; c) leverage - a high debt increases the costs of external financing, and consequently also the risk of its operations. In addition, companies with high levels of indebtedness may be less inclined to pay dividends when they use the net profit to pay off their liabilities [7]; d) growth opportunities - it is indicated that mature companies are more eager to pay out dividends due to lower investment opportunities and greater chances of obtaining cheaper capital for development [6]; e) company's size - it has been proven that larger companies pay dividends relatively more often and of greater value [17]. It may be related to the stage of the company's life cycle, its development opportunities or the sector's maturity.

Other factors determining the implementation of the dividend policy include, among others, the macroeconomic determinants, i.e., economic situation and tax system [13], legal system [7], market situation [11], as well as behavioral factors, such as the preferences of stock market investors manifested in the level of dividend premium [4], the anchoring effect [9] and mental accounting.

Moreover, further determinants of dividend payouts are the ownership concentration and ownership structure. Research on the relationship between the degree of ownership concentration and dividend payout, carried out on various markets, gave different results. The increase in dividends along with the increase in ownership concentration occurred in Great Britain [19], Czechia [5], Poland [24], Turkey [3], Malaysia [18] and Pakistan [21]. On the other hand, a decrease in dividends due to an increase in ownership concentration was observed, for example, in Germany [8].

Literature analysis regarding the impact of the ownership structure - defined as a number of shares which are held by different groups of shareholders [24] - on the dividend payout showed diversified dependencies between the amount of dividend and the type of shareholder. Starting with the managerial ownership it should be noted that some studies prove that if managers hold shares of the company, they adopt shareholders' goals, which results in higher dividend payout [20]. However, other authors claim that the amount of dividend depends on the number of shares held by managers [10]. The more concentrated managerial ownership the lower the dividend payment because managers - like other large shareholders - stop identifying their goals with those of minority shareholders and pursue their own benefits at the expense of small shareholder [16].

The literature indicates that the State Treasury and institutional investors are those shareholders that try to achieve the highest profitability. Therefore, they push for dividend payouts [20]. Having a great capital involvement in the company, these 
investors monitor and control managers to receive the dividend. Therefore, most studies show a positive relationship between institutional ownership and dividend payout [19]. Furthermore, in companies with the State Treasury as a shareholder similar behavior is observed. The State Treasury tries to receive high budget inflows, so it votes for dividends [15].

It seems that the impact of the ownership structure on the company's implementation of a specific dividend policy, and thus on the perception of this company by a stock market investor as more or less attractive in terms of investment, may depend not only on the kinds of shareholders in the company, but also on the type of first-largest shareholder. There are many different criteria for the classification of a shareholder in a joint-stock company which are used depending on the purpose of the study.

Among the most common criteria for classifying shareholders in the literature, the following are distinguished:

a) type of shareholder - in this case the division is carried out according to the investor's identity. There are the following types of investors: institutional investor, individual investor (natural person), company (legal person), manager and the State Treasury. Such a classification of investors is usually found in the academic literature (compare: [2], [24]). Detailed information is given in figure 1 ;

b) number of shares enabling real monitoring and control of the management board and influencing decisions taken at the general meeting of shareholders. In this case, the shareholders are divided into: strategic investor (holding more than $50 \%$ of votes on the general meeting of shareholders), significant investor (holding not less than $20 \%$ of votes), minority investor (holding less than $50 \%$ of votes on the general meeting of shareholders) [1];

c) investment activity - in this case shareholders are divided according to their involvement in the company's activities or investment strategy chosen by stock market investor. Taking under consideration the first of given criteria, active investors are involved in business activities by participating in general meetings, taking part in the voting process and electing the board as well as the supervisory council, while passive investors do not do this. Considering the second criterion, active investor actively invests in the capital market buying and selling shares, while passive investor is usually long-term investor who implemented buy-and-hold strategy [1];

d) obligation to provide information to the market - this division results from the necessity to inform the market about holding certain blocks of shares. In this case, it is referred to as notified shareholders (holding at least $5 \%$ of votes at the general meeting) and free float (i.e., small shareholders holding less than $5 \%$ of votes that do not have to be known to the market) [24].

\begin{tabular}{|c|c|}
\hline Type of investor & Fundamental characteristics of the shareholders \\
\hline Institutional investor & $\begin{array}{l}\text { It is an entity professionally involved in investing capital entrusted to it by third parties. It places the } \\
\text { capital of others, for example in the form of a deposit or insurance premiums, in order to achieve a higher } \\
\text { profit on investment than this from deposits or bonds. Institutional investor can be, among others, a bank, } \\
\text { an insurance company, a pension or investment fund }\end{array}$ \\
\hline $\begin{array}{c}\text { Company } \\
\text { (legal person) }\end{array}$ & $\begin{array}{l}\text { A company is a legal entity that is understood as a shareholder that is not an institutional investor. The legal } \\
\text { forms, in which the business can be run in Poland, include: sole proprietorship, civil partnership, general } \\
\text { partnership, partnership, limited partnership, limited joint-stock partnership, limited liability company and } \\
\text { joint-stock company. Additionally, companies can be divided into domestic and foreign entities }\end{array}$ \\
\hline Manager & $\begin{array}{l}\text { This is a natural person whose primary task is an implementation of the management process. In the case } \\
\text { of research on managerial ownership, this person is understood both as somebody who is employed in an } \\
\text { enterprise and who holds a certain number of shares (which could be acquired in various ways), and thus } \\
\text { also a shareholder. The double role of this person in the company is particularly difficult, as it requires } \\
\text { finding a compromise between management goals and investor goals }\end{array}$ \\
\hline $\begin{array}{l}\text { Individual investor } \\
\text { (natural person) }\end{array}$ & $\begin{array}{l}\text { It is a natural person (that is not the company's manager) making an investment of their own capital. In } \\
\text { our research they are usually notified shareholders, but in market practice the individual investors are } \\
\text { usually minority shareholders and free float, so they make smaller investments, they are often not engaged } \\
\text { in investment activities professionally, may have less knowledge and experience than other market } \\
\text { participants, and a small scale of activity prevents them from exerting a significant influence on the } \\
\text { subject of investment }\end{array}$ \\
\hline The State Treasury & $\begin{array}{l}\text { It is an institution representing the state as the owner of state property in civil-legal relations. Examples of } \\
\text { entities that may represent the State Treasury in various countries are: Ministry of State Assets, Ministry of } \\
\text { the State Treasury, Ministry of Development, etc. The tasks of the competent minister include initiating the } \\
\text { state policy in the field of management of the property of the State Treasury and protection of its interests } \\
\text { as well as management of the state property of legal persons, including the privatization of such property }\end{array}$ \\
\hline
\end{tabular}

Fig. 1. Type of investor as a criterion for classification of the shareholders

\section{The identification of previously unresolved issues and the formulation of research hypotheses}

Although the dividend policy has been the subject of scientific research since the mid-twentieth century, many issues related to dividend payout are still a research area that has not yet been investigated. One such research field is the attractiveness of investing in shares of dividend companies. Particular attention should be paid here to research on the profitability of such an investment in the context of diversification of the ownership structure. The research carried out in this area so far focuses primarily on two aspects, i.e., the correlation of ownership concentration and the amount of dividend payment, as well as the impact of the ownership structure on payout and propensity to pay dividend. 
According to the author's knowledge, there are no studies yet that would allow to determine the attractiveness of investing in shares of dividend companies in relation to the main shareholder, and as a result, to create a certain ranking list indicating the profitability of investing in dividend companies as a result of taking into account certain specific determinants of the dividend policy. Therefore, there is a justified necessity to conduct appropriate research in order to fill the observed research gap. In order to do this, the aim of the article was formulated and research questions were posed.

The purpose of this article is to examine the attractiveness of investing in shares of listed companies that regularly pay out dividends depending on the type of the first-largest shareholder. In order to achieve the aim of the paper, two following research questions were formulated:

1) in which companies, broken down by type of the first-largest shareholder, is the highest dividend payment observed?

2) considering the main shareholder, owning shares of which dividend companies is most beneficial for a stock market investor?

Then, the following hypothesis was formulated: when investing in dividend, the most attractive investments are those companies in which the most shares are held by institutional investors and the State Treasury.

\section{Research methodology and methods}

The research was carried out among the Polish joint-stock companies that were listed on the Warsaw Stock Exchange (WSE) in the period between 2005-2019. In order to achieve the aim of the article, only non-financial companies that were regular dividend payers were included in the research sample. This means that the study was conducted on those companies that paid out dividend at least three times in five consecutive years. Moreover, the condition for including the company in the research sample was obtaining all data required for analysis. The adopted criteria were met by 127 companies.

In order to answer the research questions and to verify the research hypothesis stating that when investing in dividend, the most attractive investments are those companies in which the most shares are held by institutional investors and the State Treasury, the calculation process was composed of several steps. Firstly, the companies were categorized according to basic types of the first largest shareholders (i.e., institutional investor, manager, the State Treasury, natural person and legal person). Secondly, ten financial indicators were selected to determine the synthetic indicator of the attractiveness of investment in shares of dividend payers relative to the first largest shareholder (i.e., dividend payout ratio - DivPay; dividend yield DivYield; return on equity - ReturnE; return on assets - ReturnA; current ratio of financial liquidity - Liquidi.C; quick ratio of financial liquidity - Liquid.Q; debt ratio - Debt; debt to equity ratio - Leverage; company's size - Size; opportunities of growth - Growth). The choice of such financial indicators was not accidental. The indicators were selected in such a way as to be able to assess the investment attractiveness from the point of view of a stock investor interested in dividends investing (i.e., long-term investing with dividends). Such an investor, unlike a stock market speculator, is focused mainly on receiving regular investment income in the form of dividends. Thirdly, to rank the investment attractiveness of dividend payers in relation to different types of the largest shareholder, the classical technique for order of preference by similarity to ideal solution (TOPSIS) was implemented. The use of this technique was possible after the elimination of strongly correlated variables $\left(r_{y x}\right.$ is at 0,75$)$. In order to do this, the Pearson correlation coefficient was calculated. As a result, some variables must have been excluded from further research (i.e., ReturnA and Liquid.Q), and synthetic indicator $(S I)$ - standing for the measure of investment attractiveness - took the form below:

$$
S I=f(\text { DivPay,DivYield,ReturnE,Liquid.C,Debt,Leverage,Size,Growth) }
$$

The variables remaining in the study were divided into stimulants (S) and destimulants (D). The way of variables calculation and substantiation of their assignment to one of two categories were presented in table 1.

Table 1

Stimulants and destimulants in the study regarding investment attractiveness of regular dividend payers

\begin{tabular}{|c|c|c|c|c|}
\hline Variable & Name & Way of calculation & S or D & Substantiation \\
\hline DivPay & $\begin{array}{c}\text { Dividend } \\
\text { payout ratio }\end{array}$ & $\begin{array}{l}\text { Dividend per share over } \\
\text { earnings per share }(D P S / E P S)\end{array}$ & S & $\begin{array}{l}\text { It is assumed that an increase in dividend is } \\
\text { positive for stock investor. }\end{array}$ \\
\hline DivYield & $\begin{array}{l}\text { Dividend } \\
\text { yield }\end{array}$ & $\begin{array}{l}\text { Dividend per share over market } \\
\text { share price }(D P S / P)\end{array}$ & $S$ & $\begin{array}{l}\text { An increase in dividend yield means an } \\
\text { increase in return on investment. }\end{array}$ \\
\hline ReturnE & $\begin{array}{l}\text { Return on } \\
\text { equity }\end{array}$ & $\begin{array}{l}\text { Earnings after tax over } \\
\text { shareholders equity }(E A T / E)\end{array}$ & S & $\begin{array}{l}\text { Higher company's profitability indicates } \\
\text { higher investor's return. }\end{array}$ \\
\hline Liquid.C & Current ratio & $\begin{array}{l}\text { Current assets over current } \\
\text { liabilities }(C A / C L)\end{array}$ & S & $\begin{array}{l}\text { It is proven than more liquid companies } \\
\text { pay out more dividend. }\end{array}$ \\
\hline Debt & Debt ratio & $\begin{array}{l}\text { Total liabilities over total assets } \\
(T L / T A)\end{array}$ & $\mathrm{D}$ & $\begin{array}{l}\text { Interest payment makes it more difficult to } \\
\text { pay out dividends. }\end{array}$ \\
\hline Leverage & $\begin{array}{c}\text { Debt to } \\
\text { equity ratio }\end{array}$ & $\begin{array}{l}\text { Total liabilities over } \\
\text { shareholders equity }(T L / E)\end{array}$ & $\mathrm{D}$ & $\begin{array}{l}\text { Indebted companies are usually less } \\
\text { attractive for investments. }\end{array}$ \\
\hline Size & $\begin{array}{l}\text { Size of the } \\
\text { company }\end{array}$ & $\begin{array}{l}\text { Natural logarithm of the total } \\
\text { capital }(\ln T C)\end{array}$ & $S$ & $\begin{array}{l}\text { It is proven that larger companies are more } \\
\text { eager to pay out dividend. }\end{array}$ \\
\hline Growth & $\begin{array}{c}\text { Growth } \\
\text { opportunities }\end{array}$ & $\begin{array}{l}\text { Sum of capitalization and debt } \\
\text { over total assets }(C+T L) / T A\end{array}$ & $\mathrm{D}$ & $\begin{array}{l}\text { Companies that spend more money to } \\
\text { growth pay out lower dividends. }\end{array}$ \\
\hline
\end{tabular}


In order to subject the research hypothesis to empirical verification, we used technique for order of preference by similarity to ideal solution [25]. This technique is widely used by economists for multiple criteria decision making. The best decision is that one which is the closest to the ideal solution and the farthest from the non-ideal one [22]. The decision-making process consists of four following steps: 1) normalization of the decision matrix; 2) calculation of the weighted normalized decision matrix; 3) determination of the positive and negative ideal solutions; 4) calculation of the Euclidean distance from the positive ideal solution and the negative ideal solution; 5) calculation of the relative closeness to the ideal solution The procedure to follow for each of the four steps above is detailed in table 2.

Table 2

The technique for order of preference by similarity to ideal solution

\begin{tabular}{|c|c|}
\hline Specification & Procedure of calculation \\
\hline Step 1 & $r_{i j}=\frac{x_{i j}}{\sqrt{\sum^{m} x^{2}}},(i=1,2, \ldots, m ; j=1,2, \ldots, n)$ \\
\hline Step 2 & $v_{i j}=w_{j} r_{i j},\left(i=1,2, \ldots, m ; j=1,2, \ldots n ; \sum_{j=1}^{n} w_{j}=1\right)$ \\
\hline Step 3 & $\begin{array}{l}\left.a^{+}=\left(a_{1}^{+}, a_{2}^{+}, \ldots, a_{n}^{+}\right):=\left\{\max _{i=1, \ldots, m} v_{i j} \mid j \in J_{S}\right),\left(\min _{i=1, \ldots, m} v_{i j} \mid j \in J_{D}\right)\right\} \\
\left.a^{-}=\left(a_{1}^{-}, a_{2}^{-}, \ldots, a_{n}^{-}\right):=\left\{\min _{i=1, \ldots, m} v_{i j} \mid j \in J_{S}\right),\left(\max _{i=1, \ldots, m} v_{i j} \mid j \in J_{D}\right)\right\}\end{array}$ \\
\hline Step 4 & $\begin{array}{l}S_{i}^{+}=\sqrt{\sum_{j=1}^{n}\left(v_{i j}-a_{j}^{+}\right)^{2},(i=1,2, \ldots, m ; j=1,2, \ldots, n)} \\
S_{i}^{-}=\sqrt{\sum_{j=1}^{n}\left(v_{i j}-a_{j}^{-}\right)^{2}},(i=1,2, \ldots, m ; j=1,2, \ldots, n)\end{array}$ \\
\hline Step 5 & $S I_{i}=\frac{S_{i}^{-}}{S_{i}^{+}+S_{i}^{-}},(i=1,2, \ldots, m)$ \\
\hline Symbols & $\begin{array}{l}x_{i j}-\text { the value of } j \text {-th criteria for the } i \text {-th alternative; } \\
r_{i j} \text {-the normalized value of } j \text {-th criteria for the } i \text {-th alternative; } \\
w_{j}-\text { the weight of the } j \text {-th criteria; } \\
J_{S} \text { - the set of stimulants; } \\
J_{D}-\text { the set of destimulants; } \\
\mathrm{S}^{+}-\text {the distance between the } i \text {-th alternative and the positive ideal solution; } \\
\mathrm{S}^{-}-\text {the distance between the } i \text {-th alternative and the negative ideal solution; } \\
S I_{i}-\text { synthetic indicator calculated for the } i \text {-th alternative }\end{array}$ \\
\hline
\end{tabular}

Source: Own preparation.

It should be noted that $S I_{i}$ is in the range of $\langle 0 ; 1\rangle$. The highest value of $S I_{i}$ indicates the best solution in considered problem of linear ordering (i.e., the highest investment attractiveness of dividend payers). Furthermore, the synthetic index was calculated in two ways - without weights $(S I[I])$ and with weights $(S I[I I])$. The weights were computed using the entropy method. The weight vector was calculated as follows [26]:

$$
w_{j}=\frac{1-\left[-\frac{1}{\ln (m)} \sum_{i=1}^{m} r_{i j} \ln \left(\frac{x_{i j}}{\sum_{i=1}^{m} x_{i j}}\right)\right],(j=1,2, \ldots, n)}{\sum_{j=1}^{n}\left(1-\left[-\frac{1}{\ln (m)} \sum_{i=1}^{m} r_{i j} \ln \left(\frac{x_{i j}}{\sum_{i=1}^{m} x_{i j}}\right)\right]\right),(j=1,2, \ldots, n)}
$$

The data for analysis comes from the websites of the surveyed companies and Stock Market Yearbooks published annually by the Warsaw Stock Exchange. The statistical software Statistica 13.5 and Excel were used for the calculations.

\section{Main results}

Finding the answer to the first research question (i.e., in which companies, broken down by type of the first-largest shareholder, is the highest dividend payment observed?) requires calculating the average value of dividend according to the various entities that hold the largest number of shares. Therefore, fundamental descriptive statistics were calculated. The results of this computation were presented in table 3. 
Table 3

Descriptive statistics by types of the first-largest shareholder

\begin{tabular}{|c|c|c|c|c|c|c|c|c|c|c|}
\hline Spec. & DivPay & DivYield & ReturnE & ReturnA & Liquid.C & Liquid.Q & Debt & Leverage & Size & Growth \\
\hline \multicolumn{11}{|c|}{ Panel A: Dividend payers (whole sample) } \\
\hline Mean & 0,64 & 0,06 & 0,08 & 0,15 & 2,36 & 1,81 & 0,40 & 2,68 & 13,17 & 1,54 \\
\hline Median & 0,53 & 0,04 & 0,06 & 0,10 & 1,55 & 1,20 & 0,40 & 1,59 & 12,95 & 1,18 \\
\hline Min & 0,00 & 0,00 & $-0,29$ & $-0,42$ & 0,21 & 0,21 & 0,00 & 1,02 & 10,08 & 0,13 \\
\hline Max & 1,81 & 0,86 & 0,85 & 1,37 & 15,83 & 12,52 & 1,54 & 41,91 & 20,07 & 13,74 \\
\hline Q1 & 0,39 & 0,02 & 0,03 & 0,06 & 1,13 & 0,73 & 0,24 & 1,23 & 11,81 & 0,84 \\
\hline Q3 & 0,82 & 0,06 & 0,11 & 0,17 & 2,54 & 1,87 & 0,51 & 2,03 & 14,04 & 1,65 \\
\hline S.D. & 0,39 & 0,10 & 0,12 & 0,21 & 2,60 & 2,16 & 0,23 & 5,20 & 1,93 & 1,68 \\
\hline \multicolumn{11}{|c|}{ Panel B: Institutional investors } \\
\hline Mean & 0,84 & 0,03 & 0,06 & 0,12 & 1,38 & 1,12 & 0,38 & 2,23 & 12,61 & 0,63 \\
\hline Median & 0,57 & 0,03 & 0,06 & 0,10 & 1,31 & 0,99 & 0,45 & 2,01 & 12,43 & 0,55 \\
\hline Min & 0,40 & 0,02 & 0,01 & 0,02 & 0,69 & 0,37 & 0,00 & 1,53 & 11,10 & 0,39 \\
\hline Max & 1,81 & 0,04 & 0,11 & 0,25 & 2,19 & 2,13 & 0,63 & 3,37 & 14,47 & 1,02 \\
\hline Q1 & 0,50 & 0,03 & 0,02 & 0,02 & 0,97 & 0,40 & 0,29 & 1,88 & 11,50 & 0,45 \\
\hline Q3 & 0,91 & 0,03 & 0,09 & 0,20 & 1,72 & 1,70 & 0,54 & 2,36 & 13,55 & 0,73 \\
\hline S.D. & 0,56 & 0,01 & 0,04 & 0,10 & 0,56 & 0,75 & 0,24 & 0,69 & 1,33 & 0,24 \\
\hline \multicolumn{11}{|c|}{ Panel C: Managers } \\
\hline Mean & 0,49 & 0,05 & 0,07 & 0,13 & 2,78 & 1,90 & 0,38 & 1,83 & 12,31 & 2,19 \\
\hline Median & 0,46 & 0,03 & 0,08 & 0,10 & 1,82 & 1,33 & 0,31 & 1,39 & 12,14 & 1,27 \\
\hline Min & 0,00 & 0,00 & $-0,29$ & $-0,42$ & 0,21 & 0,21 & 0,03 & 1,02 & 10,08 & 0,44 \\
\hline Max & 1,52 & 0,15 & 0,29 & 0,52 & 15,83 & 8,05 & 1,54 & 9,08 & 15,43 & 13,74 \\
\hline Q1 & 0,28 & 0,02 & 0,04 & 0,05 & 1,38 & 1,06 & 0,22 & 1,18 & 11,43 & 0,90 \\
\hline Q3 & 0,69 & 0,07 & 0,11 & 0,18 & 3,14 & 2,07 & 0,46 & 1,65 & 12,86 & 2,11 \\
\hline S.D. & 0,32 & 0,04 & 0,10 & 0,17 & 2,94 & 1,60 & 0,29 & 1,62 & 1,33 & 2,66 \\
\hline \multicolumn{11}{|c|}{ Panel D: State Treasury } \\
\hline Mean & 0,72 & 0,05 & 0,05 & 0,08 & 3,28 & 3,01 & 0,37 & 4,62 & 15,54 & 1,16 \\
\hline Median & 0,72 & 0,03 & 0,04 & 0,06 & 2,08 & 1,72 & 0,38 & 2,69 & 16,34 & 0,90 \\
\hline Min & 0,24 & 0,01 & 0,01 & 0,02 & 0,79 & 0,62 & 0,15 & 1,81 & 10,13 & 0,53 \\
\hline Max & 1,61 & 0,16 & 0,13 & 0,21 & 12,52 & 12,52 & 0,57 & 19,10 & 20,07 & 2,44 \\
\hline Q1 & 0,40 & 0,02 & 0,03 & 0,05 & 1,43 & 0,99 & 0,29 & 1,96 & 13,51 & 0,76 \\
\hline Q3 & 0,82 & 0,05 & 0,05 & 0,13 & 2,12 & 1,97 & 0,48 & 3,38 & 17,43 & 1,30 \\
\hline S.D. & 0,40 & 0,05 & 0,03 & 0,06 & 3,48 & 3,61 & 0,13 & 5,51 & 2,95 & 0,60 \\
\hline \multicolumn{11}{|c|}{ Panel E: Individual investors (natural persons) } \\
\hline Mean & 0,67 & 0,06 & 0,10 & 0,14 & 1,35 & 1,10 & 0,39 & 1,48 & 12,52 & 1,53 \\
\hline Median & 0,75 & 0,05 & 0,08 & 0,12 & 1,17 & 1,02 & 0,44 & 1,42 & 12,72 & 1,24 \\
\hline Min & 0,16 & 0,02 & 0,02 & 0,08 & 0,57 & 0,43 & 0,05 & 1,10 & 10,58 & 0,89 \\
\hline Max & 1,00 & 0,10 & 0,27 & 0,28 & 3,14 & 2,23 & 0,70 & 2,00 & 13,99 & 3,45 \\
\hline Q1 & 0,59 & 0,03 & 0,05 & 0,09 & 0,76 & 0,67 & 0,28 & 1,25 & 12,06 & 1,00 \\
\hline Q3 & 0,83 & 0,08 & 0,09 & 0,16 & 1,36 & 1,26 & 0,46 & 1,66 & 13,13 & 1,39 \\
\hline S.D. & 0,27 & 0,03 & 0,08 & 0,07 & 0,86 & 0,59 & 0,20 & 0,31 & 1,08 & 0,88 \\
\hline \multicolumn{11}{|c|}{ Panel F: Companies (legal persons) } \\
\hline Mean & 0,76 & 0,07 & 0,09 & 0,18 & 2,53 & 2,09 & 0,41 & 3,06 & 13,37 & 1,25 \\
\hline Median & 0,63 & 0,04 & 0,05 & 0,09 & 1,44 & 1,03 & 0,47 & 1,41 & 13,36 & 1,17 \\
\hline Min & 0,14 & 0,01 & 0,00 & 0,00 & 0,39 & 0,34 & 0,00 & 1,00 & 11,12 & 0,13 \\
\hline Max & 2,23 & 0,86 & 0,85 & 1,37 & 16,82 & 16,82 & 0,88 & 41,91 & 16,96 & 3,04 \\
\hline Q1 & 0,43 & 0,03 & 0,04 & 0,06 & 1,06 & 0,69 & 0,24 & 1,20 & 12,05 & 0,86 \\
\hline Q3 & 1,00 & 0,06 & 0,11 & 0,15 & 2,34 & 1,84 & 0,54 & 2,05 & 14,17 & 1,51 \\
\hline S.D. & 0,47 & 0,15 & 0,14 & 0,28 & 3,33 & 3,36 & 0,21 & 7,14 & 1,47 & 0,61 \\
\hline
\end{tabular}

Source: Own calculations on the basis of data from the websites of the surveyed companies and Stock Market Yearbooks

The results of the analysis of companies in which the first-largest shareholder was an individual investor showed that these companies paid out the highest dividends. The average dividend payout ratio was 0,84 , which means that in these companies on average $84 \%$ of net profit was transferred to their shareholders. This value was higher than the average value of the dividend payment in the entire research group, for which the average DivPay was $64 \%$. Moreover, also the median, minimum and maximum value, as well as the value of the first and third quartiles of that indicator were higher in relation to the whole research group and amounted to $40 \%, 181 \%$ (the highest observed value), $50 \%$ and $91 \%$, respectively. It should be noted that in the case of companies with an institutional investor held the most shares, the dividend yield was the lowest in the entire 
group - both the average and the median amounted to $3 \%$, which means that high dividend was accompanied with high market share price of such companies. Also profitability and financial liquidity were below average (however, it is worth adding that the value of these ratios was high, and in the case of liquidity, they were even higher than the reference values (1,38 and 1,12, respectively). A positive feature of these companies - from the point of view of investing in dividends - were lower than average debt ratios (Debt was 0,38, and Leverage was 2,23) and growth ratio (average Growth was 0,63 and was the lowest in the research group).

The lowest average value of the dividend payout was observed in the case of companies where the main shareholder was a manager. In this case, all descriptive statistics were lower than those calculated for all studied companies. The average value of dividend payout ratio was $49 \%$, and the median was $46 \%$. The average dividend yield was $5 \%$ and the median was $3 \%$. These companies were profitable and liquid (liquidity ratios exceeded the reference values and were higher than the average for the research group). The average debt of these companies was lower than in the case of the average debt calculated for all the surveyed companies (Debt was 0,38, and Leverage was 1,83). Moreover, these companies were characterized by the highest growth potential in the entire group (Growth was at the level of 2,19).

In the case of companies in which the main shareholder was the State Treasury, the average dividend payout ratio was higher than the average value calculated for the research group (mean and median were $72 \%$ ), and dividend yield was lower than average (mean $5 \%$, median $3 \%$ ). It is worth noting that these companies were the least profitable entities (return on equity was $5 \%$, and return on assets was $8 \%$ ) and over liquid (average liquidity ratios were the highest in the entire group; current ratio was 3,28 , and quick ratio was 3,01). These companies were also highly indebted. The average debt-to-equity ratio was the highest in the group and equal to 4,62. Moreover, these companies were the largest (Size was 15,54), and their development opportunities were lower than the average calculated for the study group.

The analysis of companies in which the main shareholder was an individual investor showed that the average level of dividend payment is slightly higher for them than for the entire research sample. The average value of the dividend payout ratio was $67 \%$, and the median was $75 \%$. On the other hand, the average value of the dividend yield was the same as the average in the research sample and equal to $6 \%$. Furthermore, they were profitable and liquid companies. However, the average liquidity was lower than in the research group. Moreover, they were relatively low-indebted companies (Debt was 0,38, and Leverage 1,48), smaller (Size was 12,57) and with average growth potential (Growth was 1,53).

The last analyzed group were companies in which the first-largest shareholder were legal persons. In this group of companies, it was observed that most of the analyzed financial ratios (except for the Growth indicator) were higher than the average values. These companies paid out dividend representing an average of $76 \%$ of net profit, and the dividend yield was $7 \%$. These companies were profitable (return on equity was $9 \%$ and return on assets was very high - amounting to $18 \%$ ) and over liquid (current ratio was 2,53 and quick ratio was 2,09). These companies were characterized by above-average debt (debt ratio was 0,41 , and debt-to-equity ratio was 3,06). Moreover, they were large companies (Size amounted to 13,37), with lower than average growth opportunities (Growth was at the level of 1,25).

The applicability of technique for order of preference by similarity to ideal solution requires the calculation of correlation between the studied variables. Therefore, table 4 presents the Pearson correlation matrix, i.e., it shows the coefficients of the pairwise correlation between ten variables used in the empirical research. The highest (above 0,75) and most statistically significant correlation was observed for Liquid.C and Liquid. $Q\left(r_{y x}=0,94\right)$, as well as for ReturnE and ReturnA $\left(r_{y x}=0,87\right)$. The achieved results indicate the need to remove the most strongly correlated variables from further studies. As a result, it was necessary to remove two variables, i.e. Liquid. $Q$ and ReturnA, and leave eight remaining variables to conduct the study at later stages of computation.

Table 4

Pearson correlation matrix

\begin{tabular}{ccccccccccc}
\hline Spec. & DivPay & DivYield & ReturnE & ReturnA & Liquid.C & Liquid.Q & Debt & Leverage & Size & Growth \\
\hline DivPay & 1,00 & $\mathbf{0 , 4 5}$ & 0,21 & $\mathbf{0 , 2 6}$ & 0,09 & 0,06 & $\mathbf{0 , 3 2}$ & $\mathbf{0 , 3 2}$ & 0,16 & 0,05 \\
\hline DivYield & $\mathbf{0 , 4 5}$ & 1,00 & $\mathbf{0 , 7 4}$ & $\mathbf{0 , 6 8}$ & $\mathbf{0 , 5 4}$ & $\mathbf{0 , 5 6}$ & $\mathbf{0 , 4 7}$ & $\mathbf{0 , 6 0}$ & 0,23 & $\mathbf{0 , 6 6}$ \\
\hline ReturnE & 0,21 & $\mathbf{0 , 7 4}$ & 1,00 & $\mathbf{0 , 8 7}$ & $\mathbf{0 , 5 4}$ & $\mathbf{0 , 5 6}$ & $\mathbf{0 , 3 3}$ & $\mathbf{0 , 4 7}$ & $\mathbf{0 , 2 8}$ & $\mathbf{0 , 6 4}$ \\
\hline ReturnA & $\mathbf{0 , 2 6}$ & $\mathbf{0 , 6 8}$ & $\mathbf{0 , 8 7}$ & 1,00 & $\mathbf{0 , 3 9}$ & $\mathbf{0 , 4 1}$ & $\mathbf{0 , 4 8}$ & $\mathbf{0 , 4 1}$ & $\mathbf{0 , 2 9}$ & $\mathbf{0 , 5 9}$ \\
\hline Liquid.C & 0,09 & $\mathbf{0 , 5 4}$ & $\mathbf{0 , 5 4}$ & $\mathbf{0 , 3 9}$ & 1,00 & $\mathbf{0 , 9 4}$ & 0,01 & $\mathbf{0 , 3 5}$ & 0,13 & $\mathbf{0 , 4 1}$ \\
\hline Liquid. $Q$ & 0,06 & $\mathbf{0 , 5 6}$ & $\mathbf{0 , 5 6}$ & $\mathbf{0 , 4 1}$ & $\mathbf{0 , 9 4}$ & 1,00 & 0,02 & $\mathbf{0 , 3 9}$ & 0,15 & $\mathbf{0 , 4 4}$ \\
\hline Debt & $\mathbf{0 , 3 2}$ & $\mathbf{0 , 4 7}$ & $\mathbf{0 , 3 3}$ & $\mathbf{0 , 4 8}$ & 0,01 & 0,02 & 1,00 & $\mathbf{0 , 3 3}$ & $\mathbf{0 , 2 8}$ & $\mathbf{0 , 3 1}$ \\
\hline Leverage & $\mathbf{0 , 3 2}$ & $\mathbf{0 , 6 0}$ & $\mathbf{0 , 4 7}$ & $\mathbf{0 , 4 1}$ & $\mathbf{0 , 3 5}$ & $\mathbf{0 , 3 9}$ & $\mathbf{0 , 3 3}$ & 1,00 & $\mathbf{0 , 3 1}$ & $\mathbf{0 , 3 9}$ \\
\hline Size & 0,16 & 0,23 & $\mathbf{0 , 2 8}$ & $\mathbf{0 , 2 9}$ & 0,13 & 0,15 & $\mathbf{0 , 2 8}$ & $\mathbf{0 , 3 1}$ & 1,00 & 0,16 \\
\hline Growth & 0,05 & $\mathbf{0 , 6 6}$ & $\mathbf{0 , 6 4}$ & $\mathbf{0 , 5 9}$ & $\mathbf{0 , 4 1}$ & $\mathbf{0 , 4 4}$ & $\mathbf{0 , 3 1}$ & $\mathbf{0 , 3 9}$ & 0,16 & 1,00 \\
\hline B & & & & & & &
\end{tabular}

Bold - statistical significance at 0,05 ;

Source: Own calculations on the basis of data from the websites of the surveyed companies and Stock Market Yearbooks

In order to answer the second research question (i.e., considering the main shareholder, owning shares of which dividend companies is most beneficial for a stock market investor?) and empirically verify the research hypothesis (i.e., when investing in dividend, the most attractive investments are those companies in which the most shares are held by institutional investors and the State Treasury) the relative closeness to the ideal solution for different types of the largest shareholder in regular 
dividend payers was calculated. The values of synthetic indicator $(S I)$ calculated using equal weights and weights computed using entropy method, as well as assigned ranks $(R)$ were presented in table 5.

Table 5

Relative closeness to the ideal solution for different types of the largest shareholder in regular dividend payers - values of synthetic indicator and ranks

\begin{tabular}{ccccc}
\hline Type of the largest shareholder & $\boldsymbol{S I}[\mathbf{I}]$ & Rank $\left(\boldsymbol{R}_{\boldsymbol{I}}\right)$ & $\boldsymbol{S I}[\mathbf{I I}]$ & $\mathbf{R a n k}\left(\boldsymbol{R}_{\boldsymbol{I I}}\right)$ \\
\hline Institutional investor & 0,54 & $2 / 3$ & 0,63 & 1 \\
\hline Manager & 0,47 & 4 & 0,52 & 4 \\
\hline State Treasury & 0,45 & 5 & 0,42 & 5 \\
\hline Individual investor (natural person) & 0,54 & $2 / 3$ & 0,59 & 2 \\
\hline Company (legal person) & 0,65 & 1 & 0,57 & 3 \\
\hline
\end{tabular}

Symbols: SI - synthetic indicator computed using method of equal weights [I], and entropy method [II];

Source: Own calculations on the basis of data from the websites of the surveyed companies and Stock Market Yearbooks

On the basis of the value of synthetic indicator calculated using equal weights it can be concluded that the highest investment attractiveness is seen in those dividend payers in which companies, institutional investors and individual investors are the first-largest shareholders. For such companies, the value of synthetic indicator is equal to 0,65 in the case of dividend companies in which legal person is the first-largest shareholder and 0,54 in regular dividend payers with the largest number of shares belonging to the institutional or individual investor. In fourth place in terms of the attractiveness of investing in dividend companies were those in which the manager was the largest shareholder. In this case, the value of the synthetic indicator was 0,47 . The last place in the ranking was taken by companies in which the State Treasury was the largest shareholder. In this case, the synthetic indicator was the lowest and equal to 0,45 .

If synthetic indicator was calculated using the entropy method, the obtained values were similar. The top three included again the dividend companies dominated by individual investors, institutional investors and companies, but this time the study showed that the most attractive investments are companies in which institutional investors hold the most shares. In this case, the synthetic indicator was the highest and amounted to 0,63. For individual investors $S I$ was equal to 0,59 and for companies was 0,57 . As in the previous survey, the fourth position was taken by companies whose manager was the main shareholder (the synthetic indicator was 0,52 ). The dividend companies in which the State Treasury held the most shares again came the last. In this case, the $S I$ was only 0,42 .

\section{Concluding remarks}

Research conducted on Polish listed companies that regularly paid out dividends in the years 2005-2019 in the context of the attractiveness of investing in dividends showed the presence of certain characteristics of companies considered according to the types of the first- largest shareholder. The results of research allowed to answer the first research question and showed that the highest dividends were paid out by those companies in which institutional investors, as well as legal persons (companies) and the State Treasury held the most shares. The obtained results are in line with the adopted research assumptions and literature, in which it is indicated that institutional investors, companies and the State Treasury, being usually long-term investors, are mainly focused on realizing long-term profits in the form of dividend. Moreover, these entities usually have a great capital involvement in the company, so they not only monitor managers but also gain real control over them and, among others, strive to receive great dividend.

Answering the second research question and referring to the empirical verification of the research hypothesis, it should be pointed out that the most attractive investments (in terms of stock market investor interested in dividend investing) turned out to be shares of companies in which the first-largest shareholder was an institutional investor, individual investor or legal person (company). In all these companies, the average value of dividend payout ratio was higher than for entire research group. The result achieved by the companies whose largest shareholder was the State Treasury seems to be a surprise. Although these companies usually pay out a high dividend due to the need to provide regular inflows to the state budget, the values of their other financial ratios reduced their investment attractiveness. In particular, attention should be paid to their very high debt in relation to equity, which usually negatively affects the perception of the possibility of making a profit by a stock market investor and, in the event of a possible bankruptcy of the company, indisposes the investor to return the capital. Despite the payment of regular and high dividends by State Treasury companies, which was primarily intended to constitute a source of income for the state budget, these companies were not in the best financial condition. In addition to the above-indicated high leverage, they were characterized by the lowest profitability among all surveyed companies, and a very high excess liquidity may indicate improper financial management. Therefore, the companies in which the State Treasury had the most shares turned out to be the least attractive for investments. It is also worth adding that the investment attractiveness of companies in which the manager was the first-largest shareholder was higher than that of companies with State Treasury shareholding, despite the fact that they paid out the lowest dividends. A low dividend may be in this case associated with the separation of ownership from management and the role of managers in the company, even if they hold shares. According to the agency theory and the separation of ownership from management in joint-stock companies, the goals of managers and shareholders may differ significantly, and dividend payout (so expected by the owners of the company) may be perceived by the manager as an 
unnecessary transfer of net profit outside the company which indisposes the company to develop and grow using its equity. However, to confirm these assumptions, it will be necessary to conduct further research in this area in the future.

Our research has some limitations: a) it applies only to Polish listed companies that regularly paid out dividends in the study period; b) the construction of the synthetic indicator of investment attractiveness is based only on those financial indicators that are indicated in the literature as the key determinants of dividend policy; c) it applies only to the companies listed on the WSE in the fifteen-year research period, without dividing it into prosperity and decline periods.

\section{References:}

1. Adamska, A. (2012), «Zmiany akcjonariatu spółek publicznych w dobie kryzysu», Studia i Prace Kolegium Zarządzania i Finansów, Vol. 117, pp. 36-53.

2. Aluchna, M. (2007), Mechanizmy corporate governance w spótkach giełdowych, Szkoła Główna Handlowa w Warszawie - Oficyna Wydawnicza, Warszawa, $308 \mathrm{p}$.

3. Aydin, A.D. and Cavdar, S.C. (2015), «Corporate Governance and Dividend Policy: An Empirical Analysis From Bursa Istanbul Corporate Governance Index», Accounting and Finance Research, Vol. 4 (3), pp. 66-76, doi: http://dx.doi.org/10.5430/afr.v4n3p66.

4. Baker, M. and Wurgler, J. (2004), «Appearing and Disappearing Dividends: the Link to Catering Incentives», Journal of Financial Economics, Vol. 73 (2), pp. 271-288, doi: http://dx.doi.org/10.1016/j.jfineco.2003.08.001.

5. Claessens, S. and Djankov, S. (1999), «Ownership Concentration and Corporate Performance in the Czech Republic», Journal of Comparative Economics, Vol. 27 (3), pp. 498-513.

6. DeAngelo, H., DeAngelo, L. and Stulz, R. (2006), «Dividend policy and the earned/contributed capital mix: a test of the life-cycle theory», Journal of Financial Economics, Vol. 81 (2), pp. 227-254, doi: 10.1016/j.jfineco.2005.07.005.

7. Eije, H. and Megginson, W.L. (2008), «Dividends and share repurchases in European Union», Journal of Financial Economics, Vol. 89 (2), pp. 347-374, doi: 10.1016/j.jfine-co.2007.11.002.

8. Elson, J.A., Hofler, R. and Lee, J. (2011), «Dividend Policy and Institutional Ownership: Empirical Evidence using a Propensity Score Matching Estimator», Journal of Accounting and Finance, Vol. 11 (1), pp. 105-122.

9. Fisher, K.L. and Statman, M. (2000), «Cognitive Biases In Market Forecast», Journal of Portfolio Management, Vol. 27 (1), pp. $72-81$, doi: http://dx.doi.org/10.3905/jpm.2000.319785.

10. Florackis, C., Kanas, A. and Kostakis, A. (2015), «Dividend policy, managerial ownership and debt financing: A nonparametric perspective», European Journal of Operational Research, Vol. 241, pp. 783-795, doi: http://dx.doi.org/10.1016/j.ejor.2014.08.031.

11. Gajdka, J. (2013), Behawioralne finanse przedsiębiorstw. Podstawowe podejścia i koncepcje, Publisher of the University of Lodz, Lodz, pp. 226.

12. Kaźmierska-Jóźwiak, B. (2014), «Czynniki polityki dywidendowej w warunkach polskich», Annales Universitatis Mariae CurieSktodowska, Vol. 48, pp. 129-135.

13. Kowerski, M. (2010), «Wpływ nastrojów gospodarczych przedsiębiorców i konsumentów na decyzje dywidendowe spółek kapitałowych», Barometr Regionalny, Vol. 2 (20), pp. 19-34.

14. La Porta, R., Lopez, F., Shleifer, A. and Vishny, R. (2000), «Agency problems and dividend policies around the world», Journal of Finance, Vol. 55 (1), pp. 1-33, doi: 10.1111/0022-1082.00199.

15. Liljeblom, E. and Maury, B. (2016), «Shareholder Protection, Ownership, and Dividends: Russian Evidence», Emerging Markets Finance \& Trade, Vol. 52, pp. 2414-2433, doi: http://dx.doi.org/10.1080/1540496X.2015.1073991.

16. Neves, E. (2014), «Ownership structure and investors sentiments for dividends», International Journal of Financial Research, Vol. 5 (2), pp. 35-58.

17. Pieloch-Babiarz, A. (2017), «Determinants of payout policy and investment attractiveness of companies listed on the Warsaw Stock Exchange», Equilibrium. Quarterly Journal of Economics and Economic Policy, Vol. 12 (4), pp. 675-691, doi: 10.24136/eq.v12i4.35.

18. Ramli, N.M. (2010), «Ownership Structure and Dividend Policy. Evidence from Malaysian Companies», International Review of Business Research Papers, Vol. 6 (1), pp. 170-180.

19. Short, H., Zhang, H. and Keasey, K. (2002), «The Link Between Dividend Policy and Industrial Ownership», Journal of Corporate Finance, Vol. 8, pp. 105-122.

20. Smith, D.D., Pennathur, A.K. and Marciniak, M.R. (2017), «Why do CEOs agree to the discipline of dividends?», International Review of Financial Analysis, Vol. 52, pp. 38-48, doi: http://dx.doi.org/10.1016/j.irfa.2017.04.010.

21. Ullah, H., Fida, A. and Khan, S. (2012), «The Impact of Ownership Structure on Dividend Policy. Evidence form Emerging Markets KSE-100 Index Pakistan», International Journal of Business and Social Science, Vol. 3 (9), pp. $289-307$.

22. Wang, P., Li, Y., Wang, Y.H., and Zhu, Z.Q. (2015), «A new method based on TOPSIS and Response Surface Method for MCDM problems with interval numbers», Mathematical Problems in Engineering, April, doi: 10.1155/2015/ 938535.

23. Wawryszuk-Misztal, A. (2016), «Zmiany w strukturze akcjonariatu polskich spółek giełdowych zmieniających rynek notowań akcji», Acta Universitatis Lodziensis. Folia Oeconomica, Vol. 4 (323), pp. 141-153.

24. Wypych, M. (2015), «Koncentracja własności a wypłata dywidend na przykładzie przemysłowych spółek giełdowych», Zeszyty Naukowe Uniwersytetu Szczecińskiego. Finanse, Rynki Finansowe, Ubezpieczenia, Vol. 73, pp. 783-792.

25. Yoon, K. (1987), «A reconciliation among discrete compromise solutions», Journal of the Operational Research Society, Vol. 38 (3), pp. 277-286, doi: 10.1057/jors.1987.44.

26. Zhang, H. (2015), «Application on the entropy method for determination of weight of evaluating index in fuzzy mathematics for wine quality assessment», Advance Journal of Food Science and Technology, Vol. 7 (3), pp. 195-198, doi: 10.19026/ajfst.7.1293.

\footnotetext{
** How to cite this article: Pieloch-Babiarz A. The first-largest shareholder and the attractiveness of investing in Polish dividend companies. Public Policy and Accounting. 2021, Vol. 1 (3). https://doi.org/10.26642/ppa-2021-1(3)-3-11.
} 